\title{
HAND HYGIENE AMONG HOSPITAL STAFF: A SURVEY OF KNOWLEDGE, ATTITUDE, AND PRACTICE IN A GENERAL HOSPITAL IN SYRIA
}

\author{
Maha Othman $^{1}$, Cornelis Jonker ${ }^{2 *}$ \\ 1. Department of Quality Control and Health Education, Gheras International School, Al Dafna Doha, Qatar \\ 2. Faculty of Health Studies, University of Bradford, Bradford, United Kingdom \\ *E-mail:C.Jonker@bradford.ac.uk
}

\begin{abstract}
Poor hand-hygiene adherence endangers the safety of both healthcare workers and patients. A cross-sectional Knowledge Attitudes Practicing (KAP) survey $(n=268)$ and an observation of hand-hygiene compliance $(n=36)$ were conducted among staff in a general hospital in Syria. The aim of this study was to investigate the degree of compliance with hand hygiene protocols by general health care workers including their knowledge, attitude and practice. The mean overall observed hand-hygiene compliance rate was 45.7\% (95\% CI 37.1 - 54.3). Nurses were observed to have better compliance than physicians. Staff were observed to be more concerned in performing hand-hygiene after than before patient contact (before mean $=32.0 \%$, after mean $=51.2 \%, p<0.05$ ). The questionnaire showed that there was a significant correlation between knowledge, attitude, and facilities on the one hand and poor self-reported adherence on the other. Multivariate analysis showed that poor adherence was statistically significantly associated with males (63.5\%), untrained staff (58.5\%) and unavailability of washing basins (60.4\%). Poor adherence was high in ICU, among younger and unaware participants.
\end{abstract}

Keywords: compliance, hand hygiene, hospital acquired infection, healthcare workers, Knowledge-Attituded-Practice $(K A P)$, patient safety

\section{Abstrak}

Kepatuhan pada kebersihan tangan yang buruk membahayakan keselamatan tenaga kesehatan dan pasien. Survei potong lintang Pengetahuan Sikap Praktek $(n=268)$ dan observasi kepatuhan kebersihan tangan $(n=36)$ dilakukan di antara staf di rumah sakit umum di Suriah. Tujuan dari penelitian ini adalah untuk mengidentifikasi tingkat kepatuhan dengan protokol kebersihan tangan oleh tenaga kesehatan termasuk pengetahuan, sikap dan praktik mereka. Rerata tingkat kepatuhan kebersihan tangan yang diamati secara keseluruhan adalah 45,7\% (95\% CI 37,1-54,3). Perawat diamati memiliki kepatuhan yang lebih baik daripada dokter. Staf yang diamati tampak lebih peduli melakukan kebersihan tangan setelah kontak dengan pasien dibanding sebelum kontak (rerata sebelum $=32,0 \%$, rerata setelah $=51,2 \%$, $\mathrm{p}<$ $0,05)$. Hasil kuesioner menunjukkan bahwa ada korelasi yang signifikan antara pengetahuan, sikap, dan fasilitas, namun disisi lain kepatuhan dilaporkan buruk. Analisis multivariat menunjukkan bahwa kepatuhan yang buruk secara statistik terkait secara signifikan dengan jenis kelamin laki-laki (63,5\%), staf tidak terlatih $(58,5 \%)$ dan tidak tersedianya tempat cuci tangan $(60,4 \%)$. Tingkat kepatuhan yang rendah angkanya ditemukan cukup tinggi di ICU, di antara responden yang lebih muda dan tidak sadar.

Kata Kunci: kebersihan tangan, kepatuhan, hospital acquired infection, tenaga kesehatan, keselamatan pasien, Pengetahuan-Sikap-Praktik

\section{Introduction}

Health care-associated infections occur worldwide. These infections have been identified for more than 150 years and are still considered a hazard to both patients and health care workers
(Chandra \& Milind, 2001). The estimated rates of health care associated infections also emphasize that at any time, hundreds of millions of people worldwide are suffering from infections acquired in health-care facilities (WHO, 2009a, 2011). In developing countries, the risk 
of health care associated infections is higher than that in developed countries and the proportion of patients affected by health care associated infections can exceed $25 \%$. Most of these infections spread from one patient to another by the hands of health care workers (WHO, 2009b).

Hand hygiene is a general term referring to any action of hand-cleansing. It is recognized as the most effective way to control infections (The Joint Commission, 2009). Hand hygiene applies to handwashing, antiseptic handwash, alcohol-based hand rub, or surgical antisepsis. Some studies disclosed significant differences in adherence to hand hygiene in different hospitals (WHO, 2009b). Other studies evaluated adherence to hand hygiene before and after patients' contact (Novoa, Pi-Sunyer, Sala, Molins, \& Castells, 2007).

More attention is being paid to evaluations of adherence to hand hygiene practices in specific wards where hand hygiene is considered to be a more critical issue (Pittet, Mourouga \& Perneger, 1999). Adherence to hand hygiene varies according to the profession of health care workers (Rosenthal, Guzman, \& Safdar, 2005; Trick, et al., 2007; WHO, 2009b). Health care workers adherence toward hand hygiene is also influenced significantly by the behaviour and presence of other health care workers (Lankford, et al., 2003; Mauritio, et al., 2014), by the distance to sinks (Deyneko, Cordeiro, Berlin, BenDavid, Perna \& Longtin, 2016), and by socialisation and emotions (Loveday, Lynam, Singleton, \& Wilson, 2014).

The aim of this study was to investigate the degree of compliance with hand hygiene protocols by general health care workers, identifying their knowledge and attitude in order to provide a baseline assessment for an intervention plan. This research is important for Syria because of the paucity of evidence on this topic in this country. Hand hygiene is a crucial issue to improve the quality of health care services in Syrian health care facilities.

\section{Methods}

Design. This cross-sectional study combined observations with a survey using a structured questionnaire in order to obtain more details about hand hygiene and to improve validity. The observational study was conducted to investigate actual practices among physicians, residents and nurses. The observation involved four wards' morning shifts only.

The survey was conducted among staffs including physicians, residents and nurses of all 8 wards $(\mathrm{N}=299)$.

Sample. This study involved 268 health care workers for survey. The observations covered physicians, residents and nurses. A quota sampling method was followed $(n=36)$. Three participants of each profession on each ward were observed. Observed health care workers are forming $40 \%$ of overall health care workers available on these four wards in morning shift only.

Setting. The study was conducted in a general hospital that is part of a large medical complex that also comprises two specialist hospitals. This hospital has 150 beds across eight different wards. These wards also provide counselling health services and other secondary health services such as laboratories and radiology. The hospital is free of charge for patients and the high demand for its services causes high workloads and a constant need for additional staff.

Data Collecting. A structured observation checklist was developed and piloted specifically for this study. The observation was conducted in two surgical wards, the emergency department and in the intensive care unit. These wards were considered to be critical wards regarding risks associated with health care associated infections during care provision. Observation duration lasted for one hour for each of the included health care workers. Confidentiality was important and privacy of both pa- 
tient and health care workers were taken into consideration.

Two types of time indication of hand hygiene opportunities were recognized; before patient contact and after patient contact. Washing hands with soap (normal or antibacterial) or using alcohol-based hand rub (ABHR) and using gloves appropriately were counted as positive hand hygiene adherence. Non-adherence was considered if missing washing hands or washing hands with water only and failure to remove gloves between two patients or wearing the same gloves between clean and dirty practices on the same patients were considered as. The observer did not give any feedback to the health care workers regarding their hand hygiene performance.

For survey, the questionnaire was structured in order to capture knowledge, attitude, and factors associated with hand hygiene practices. The questionnaire also included a separate section on effective key interventions improving adherence to hand hygiene protocols. By means of seven points scale the researcher assessed these key actions. The last three points of the scale closest to the very effective evaluation were considered positive answers and an effective improvement action as a sequence. One open ended question was added to the questionnaire to capture any other valuable information. The questionnaire included questions about general information (gender, age, profession, qualification and ward), training, years of experience related to health care services, practices by health care workers and factors that may influence adherence to hand hygiene. Questionnaires were distributed in
Arabic after completely finishing all observational data collection.

Data were analyzed by SPSS (v.15) with entry for both observations and questionnaires data. Statistical significance was set for all tests at $\mathrm{p}<0.05$ (2-tailed) using ANOVA and t-test (multiple comparisons). For multivariate logistic regression analysis was used to perform all poor adherence group comparisons. Predictive variables were measured using odds ratios and 95\% CI.

The study was approved by the Syrian Ministry of Health for ethics purposes and by the hospital management. Health care workers were informed related to this study. Verbal informed consent was taken from all participants The leaflet also summarized the research title, aim, content, participant rights and participation procedures. The participant information leaflet was attached to each questionnaire.

\section{Results}

Analysis of the observational study showed that the overall hand hygiene compliance rate mean is $45.7 \%$ (95\% CI 37.1-54.3). Nurses were observed to have better overall hand hygiene compliance than physicians. Variations in hand hygiene compliance rate among observed health care workers with different professions are presented in Table 1.

Comparison of hand hygiene compliance rates of the four wards showed that the rate of hand hygiene compliance varied from $60.1 \%$ in Surgical Ward 1 to $26.5 \%$ in Surgical Ward 2 (Table2).

Table 1. Observed Hand Hygiene Compliance Rates by Profession

\begin{tabular}{llc}
\hline Profession & n & Compliance rate (95\% CI) \\
\hline Physician & 12 & $36.6(18.9-54.3)$ \\
Resident & 12 & $59.2(42.2-76.3)$ \\
Nurse & 12 & $41.3(31.6-51.1)$ \\
\hline
\end{tabular}


Table 2. Observed Hand Hygiene Compliance Rates in Four Wards

\begin{tabular}{lcc}
\hline Ward & $\begin{array}{c}\text { Healthcare workers } \\
\mathbf{n}\end{array}$ & $\begin{array}{c}\text { Hand hygiene compliance rate } \\
\mathbf{( 9 5 \%} \mathbf{C I})\end{array}$ \\
\hline Surgical W1 & 9 & $60.1(45.5-74.7)$ \\
Surgical W2 & 9 & $26.5(15.0-38.0)$ \\
Emergency & 9 & $53.5(30.5-76.5)$ \\
ICU & 9 & $42.8(23.9-61.8)$ \\
\hline
\end{tabular}

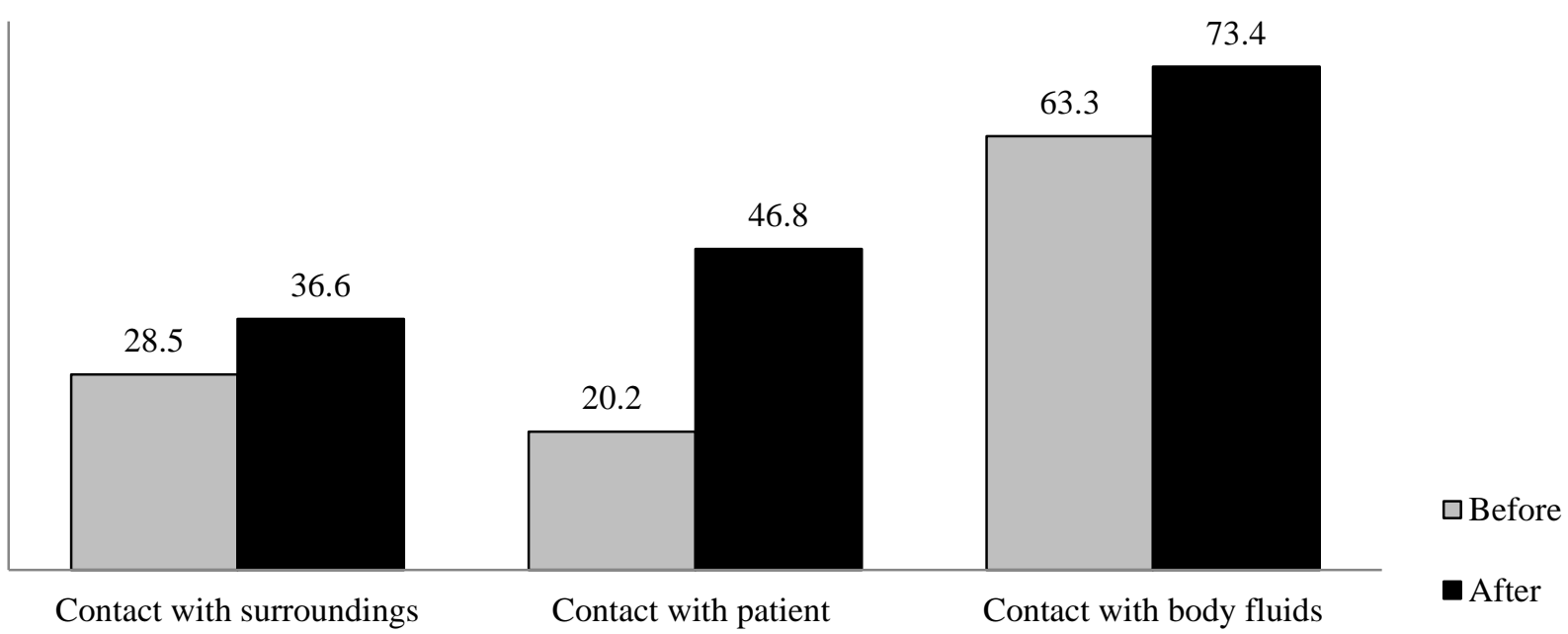

Figure 1. Full Hand Hygiene Adherence before and after contact (\%)

It showed a significant effect for the ward group on adherence to hand hygiene $(\mathrm{p}=0.02)$. It also showed a statistically significant mean difference between the lowest compliance rate in Surgical Ward 2 and the highest compliance rate in Surgical Ward 1 (mean difference= 33.6). A difference in workload between the two surgical wards may explain this difference. On average staff were observed to be more concerned in performing hand hygiene after patient contact than before patient contact (before mean $=32.0 \%$, after mean $=51.2 \%, \mathrm{p}<$ $0.05)$.

Analysis of the questionnaire gave a rather different picture of hand hygiene. The return rate of the questionnaire was very high: $89.6 \%$. Number of the participants $113(42.3 \%)$ were nurses, $80(30.0 \%)$ were residents and 74 $(27.7 \%)$ were physicians. This was similar to the distribution of all staff by the same pro- fessional groups. Since the questionnaires and observation forms were completely anonymous it was impossible to identify staff that did not participate.

A number 234 of health care workers $(87.6 \%)$ did not receive any formal training on hand hygiene protocols. The highest frequency of full adherence to hand hygiene was among participants $(n=196$, equal to $73.4 \%)$ after body fluid exposure risk which is the highest risk opportunity among all listed practices. If the dirty is visible, the health care worker will be easily aware of dirty hands and may be more concerned about their own risk of acquiring diseases from patients rather than protectting of the patients (figure 1).

The availability of washing basins was higher. It also that a higher hand hygiene score was reported by same health care workers. 
The results show that there was an interrelation between poor adherence on the one hand and attitude, knowledge and facilities on the other hand. Multivariate analysis showed that poor adherence was associated with being male (OR 0.4; $\mathrm{p}=0.00$ ), belonging to an untrained group (OR 4.4; $\mathrm{p}=0.00$ ) and unavailability of washing basins. Poor adherence was high in ICU, among younger and unaware participants. Nurses reported positive adherence to hand hygiene protocols more often than physicians (Table 3).

The results on Key Actions to improve adherence to hand hygiene practices are presented in figure 2.

Table 3. Factors Associated with Hand Hygiene Adherence (logistic regression)

\begin{tabular}{|c|c|c|c|c|c|}
\hline Factor & Value & n (\%) & $\begin{array}{c}\text { Self-Reported } \\
\text { Poor Adherence } \\
\text { n }(\%)\end{array}$ & $\begin{array}{c}\text { Univariate Odds } \\
\text { Ratio } \\
(95 \% \text { CI })\end{array}$ & $\begin{array}{c}\text { Multivariate } \\
\text { Odds Ratio } \\
(95 \% \text { CI })\end{array}$ \\
\hline Gender & $\begin{array}{l}\text { Male* } \\
\text { Female }\end{array}$ & $\begin{array}{l}156(58.4) \\
111(41.6)\end{array}$ & $\begin{array}{l}99(63.5) \\
46(41.4)\end{array}$ & $0.4(0.3-0.7)^{\#}$ & $0.4(0.2-0.6)^{\#}$ \\
\hline $\begin{array}{l}\text { AGE (Years) } \\
n=267\end{array}$ & $\begin{array}{l}19-29 * \\
29-39 \\
39<\end{array}$ & $\begin{array}{l}109(40.8) \\
96(36.0) \\
62(32.2)\end{array}$ & $\begin{array}{l}67(61.5) \\
52(54.2) \\
26(41.9)\end{array}$ & $\begin{array}{l}0.7(0.4-1.3) \\
0.5(0.2-0.9)^{\#}\end{array}$ & $\begin{array}{l}1.4(0.6-3.3) \\
0.6(0.2-2.5)\end{array}$ \\
\hline Profession & $\begin{array}{l}\text { Physician* } \\
\text { Resident } \\
\text { Nurse }\end{array}$ & $\begin{array}{c}74(27.7) \\
80(30.0) \\
113(42.3)\end{array}$ & $\begin{array}{l}37(50.0) \\
57(71.3) \\
51(45.1)\end{array}$ & $\begin{array}{c}2.5(1.3-4.8)^{\#} \\
0.8(0.5-1.5)\end{array}$ & $\begin{array}{l}1.7(0.6-4.6) \\
0.9(0.4-2.6)\end{array}$ \\
\hline $\begin{array}{l}\text { Work Experience } \\
\text { (Years) }\end{array}$ & $\begin{array}{l}1-9 * \\
9-19 \\
19<\end{array}$ & $\begin{array}{l}141(52.8) \\
79(29.6) \\
47(17.6)\end{array}$ & $\begin{array}{l}90(63.8) \\
34(43.0) \\
21(44.7)\end{array}$ & $\begin{array}{l}0.4(0.2-0.8)^{\#} \\
0.5(0.2-0.9)^{\#}\end{array}$ & $\begin{array}{l}0.8(0.3-1.9) \\
1.3(0.4-4.5)\end{array}$ \\
\hline Ward & $\begin{array}{l}\text { Surgical } 1 * \\
\text { Surgical } 2 \\
\text { Emergency } \\
\text { ICU } \\
\text { Other wards }\end{array}$ & $\begin{array}{l}52(19.5) \\
43(16.1) \\
43(16.1) \\
42(15.7) \\
87(32.6)\end{array}$ & $\begin{array}{l}29(55.8) \\
23(53.5) \\
23(53.5) \\
25(59.5) \\
45(51.7)\end{array}$ & $\begin{array}{l}0.9(0.4-2.1) \\
0.9(0.4-2.1) \\
1.2(0.5-2.7) \\
0.9(0.4-1.7)\end{array}$ & $\begin{array}{l}0.8(0.3-2.1) \\
1.0(0.4-2.5) \\
1.1(0.4-3.0) \\
0.9(0.4-2.0)\end{array}$ \\
\hline Training & $\begin{array}{l}\text { No training } \\
\text { Training* }\end{array}$ & $\begin{array}{l}234(87.6) \\
33(12.4)\end{array}$ & $\begin{array}{l}137(58.5) \\
8(24.2)\end{array}$ & $4.4(1.9-0.2)^{\#}$ & $4.4(1.8-10.5)^{\#}$ \\
\hline $\begin{array}{l}\text { Washing basins } \\
\text { availability }\end{array}$ & $\begin{array}{l}\text { Never* } \\
\text { Sometimes } \\
\text { Frequently } \\
\text { Always }\end{array}$ & $\begin{array}{l}47(17.6) \\
111(41.6) \\
55(20.5) \\
54(20.3)\end{array}$ & $\begin{array}{l}29(60.4) \\
55(63.2) \\
44(54.3) \\
17(33.3)\end{array}$ & $\begin{array}{l}1.1(0.6-2.3) \\
0.8(0.4-1.6) \\
0.3(0.1-0.7)^{\#}\end{array}$ & $\begin{array}{l}1.1(0.5-2.4) \\
0.7(0.3-1.6) \\
0.4(0.2-0.9)^{\#}\end{array}$ \\
\hline Awareness: & $\begin{array}{l}\text { Not aware } \\
\text { Aware* }\end{array}$ & $\begin{array}{r}25(9.4) \\
42(90.6)\end{array}$ & $\begin{array}{c}16(64.0) \\
129(53.3)\end{array}$ & $1.6(0.7-3.7)$ & $1.6(0.6-4.3)$ \\
\hline $\begin{array}{l}\text { Priority in } \\
\text { hospital }\end{array}$ & $\begin{array}{l}\text { Low priority* } \\
\text { Moderate } \\
\text { priority } \\
\text { High priority } \\
\text { Very high } \\
\text { priority }\end{array}$ & $\begin{array}{l}85(31.8) \\
67(25.1) \\
67(25.1) \\
48(18.0)\end{array}$ & $\begin{array}{l}54(63.5) \\
37(55.2) \\
35(52.2) \\
19(39.6)\end{array}$ & $\begin{array}{l}0.7(0.4-1.4) \\
0.6(0.3-1.2) \\
0.4(0.2-0.8)^{\#}\end{array}$ & $\begin{array}{l}0.7(0.3-1.4) \\
0.8(0.4-1.8) \\
0.6(0.3-1.4)\end{array}$ \\
\hline
\end{tabular}

* Reference group

\# Statistically significant

Note: The median of 12 (out of 18) was the adopted cut-off point between poor and good adherence scores; this cutoff point is consisted with the researcher's clinical point of view for defining poor adherence. 


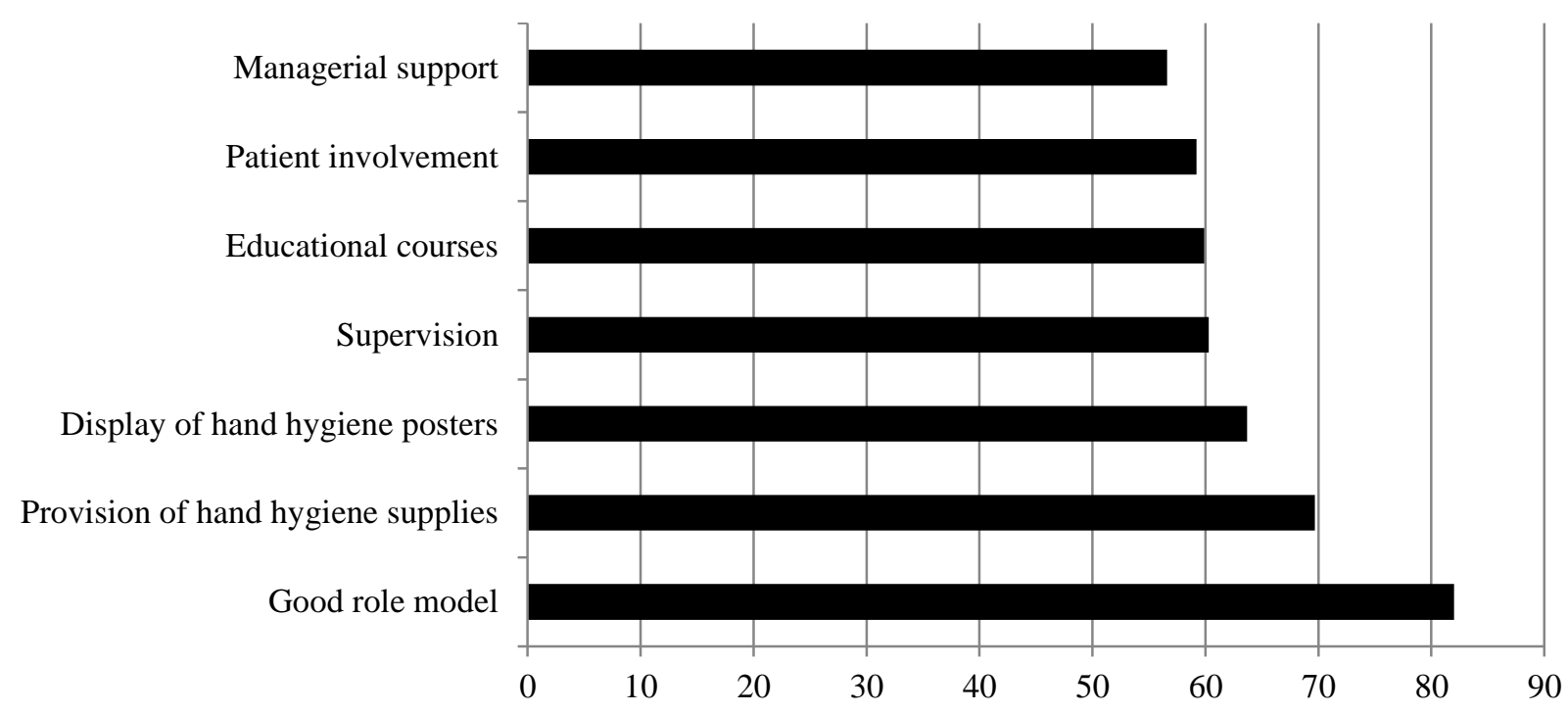

Figure 2. Reported Effectiveness of Key Actions to Improve Hand-Hygiene (\%)

\section{Discussions}

Adherence to hand hygiene among health care workers ranged between low and moderate at best measurements. The overall observed hand hygiene compliance rate by health care workers was $45.7 \%$. This percentage is consistent with previous studies in other countries, especially developing countries (Sacar, et al., 2006).

Adherences to hand hygiene practices were lower in ICU (42.8\%) and one of the surgical wards (Surgical Ward 2) $(26.1 \%)$ than in the other observed wards. The significant difference between the two surgical wards was probably due to higher workload in Surgical Ward 2 compared with Surgical Ward 1. This finding is supported by previous studies (Pittet, Mourouga, \& Perneger, 1999; Wendt, Knautz \& Von Baum, 2004). It is worth mentioning that in the researchers' opinion that in Surgical Ward 1 where the highest hand hygiene adherence was observed, teamwork was notably stronger among health care workers and that that ward had a qualified head nurse.

Nurses were observed to have better overall hand hygiene compliance than physicians. Although the health care worker's profession was not a predictive factor in univariate ana- lysis, which was probably due to insufficient number of observations, the study results were consistent with other studies conducted in neighboring countries such as in Turkey (Makay, Içöz, Yilmaz, \& Kolcu, 2008). Several international studies showed that adherence to hand hygiene protocols is lower among physicians than among other types of health care workers (Centers for Disease Control and Prevention, 2002; Rosenthal, et al., 2005; Trick et al., 2007).

Adherence to hand hygiene protocols after patient contact was higher than before patient contact. The hypothesis that there is a positive attitude towards hand hygiene adherence after patient contact was reconfirmed in this observation.

There was a statistically significant difference in overall hand hygiene score after patient contact and overall hand hygiene score before patient contact. This shows that health care workers are more concerned about their own health, about not acquiring any disease from patients, rather than about protecting patients and this is clearly a problem of attitude.

However, such attitude does not lead to protection of individual patients. The health care 
workers seem to be more concerned with protecting their own health by limiting their risk of catching infections from patients rather than with preventing transmission of pathogens present on their hands to patients (i.e. health care workers have a problem of attitude). From observation, the health care workers washed their hands only if they see the dirty things on it. Previous study reported that this behaviour was related to knowledge and attitude (Lankford, et al., 2003; Novoa, PiNunyer, Sala, Molins \& Castells, 2007; Pittet et al., 2009). The respondent was not announced which issue of infection control was being studied, when observing, so their behavior would not have been widely affected by the Hawthorne effect. This means that we consider the results to be valid (Eckmans, Bessert, Behnke, Gastmeier \& Ruden, 2006).

The written survey revealed that higher adherences were predicted for female respondents. Females are more concerned with cleansing their hands (Centers for Disease Control and Prevention, 2002; Pittet, et al., 2004; WHO, $2009 b)$. An obvious lack of training was revealed. Health care workers have a problem of education and knowledge. Higher adherences to hand hygiene protocols were strongly predicted by training status (Trick et al., 2007). Many multifaceted approaches to improve hand hygiene used training intervention to enhance good adherence (WHO, 2009b).

Availability of washing basins was strongly associated with adherence. Availability of appropriate hand hygiene supplies in general and availability of washing basins in appropriate positions in particular allows easier access for health care workers to perform acceptable hand hygiene practices (Deyneko, et al., 2016; WHO, 2009b). It is worth mentioning that the majority of respondents $(87.6 \%)$ had no training in hand hygiene and less than a third $(31.7 \%)$ reported low priority for hand hygiene within the hospital. This finding discloses lack of support by higher echelons and lack of preparation courses for health care workers before employment as well as poor endorsement of continuous learning. In contrast, nearly all respondents $(90.6 \%)$ were aware of the effectiveness of hand hygiene in preventing hospital associated infections. Even though unawarehealth care workers reported poor adherence $(64 \%)$, this was still higher than among awarehealth care workers $(53.3 \%)$ and awareness itself was not a predictive factor for hand hygiene behaviour (cf. Pittet, et al., 2004; cf. Santosaningsih, 2017).

Positive reported attitude towards hand hygiene protocols was associated with opportunities of higher risk for cross-transmission. Reported adherences were higher within invasive procedures and body fluid risk exposure. This finding is inconsistent with some previous observational studies (WHO, 2009b; Pittet et al., 2004), yet consistent with the study by Loveday, Lynam, Singleton, and Wilson (2014), but does not tally with the results of the observational part of this study. This could be explained by health care workers thinking that they do adhere whereas in reality they do not. If that is the case than that means that health care workers have an attitude problem.

Poor adherence was more prevalent among physicians than among nurses. Although profession was not shown to be a predictive factor for hand hygiene behaviour in the multivariate analysis, several observational studies showed that there is lower adherence to hand hygiene protocols among physicians than among nurses (Centers for Disease Control and Prevention, 2002; Makay, et al., 2008; Rosenthal, et al., 2005; Trick et al., 2007). In contrast, residents in this study reported lower adherence compared with other health care workers (i.e. nurses and physicians). This result is inconsistent with the results of the observational study and also with previous studies (Pittet et al., 2004). In the observational part of this study residents were seen to have higher hand hygiene compliance rates. Sample size is a limitation in this study. However, sample size is not a valid justification of the higher adhe- 
rence to hand hygiene practices. Again, social desirability could be a factor.

Comparison of the results of the observational study with the written survey shows a clear discrepancy between self-reported behaviour and actual observed behaviour. This means that either the health care workers deliberately presented themselves to be more adherent to hand hygiene guidelines than they were in reality or that health care workers had the wrong self-image regarding their hand hygiene practice, or both. Either way this can be considered an attitude problem. It is worth highlighting that scientific research in general and health studies in particular are new concepts in Syria and are incongruent with the existing blame culture in Syrian hospitals. This may have affected self-reported answers despite confidentiality assurance.

There was a trend towards better hand hygiene behaviour among older health care workers and those with long work experience. Participants reported higher adherences to hand hygiene protocols after patient contact opportunities than before patient contact opportunities. This finding is supported by the results of the observational study and this could be seen as a sign of internal validity.

The study defined multiple predictive factors for hand hygiene adherence behavior. These factors include gender, training, and availability of washing basins (i.e. attitude, knowledge and facilities). A notable positive adherence was reported after patient contact. A trend towards better adherence was identified among nurses compared to other health care workers. It is worth mentioning that ICU reported the highest poor adherence percentage of all wards. Poor adherence was also high among unaware health care workers and younger health care workers.

Since hand hygiene behaviour in this study was found to be predictable by multiple factors related to attitude, knowledge and facilities, a multimodal improving policy should be adopted. Considering hand hygiene adherence among physicians was found to be lower than among nurses, improving hand hygiene behaviour among physicians specifically may enhance improving overall hand hygiene adherence among all health care workers (Pittet, et al., 2004). It is clear that any hand hygiene improvement program should involve educational and training courses as these have shown to have, albeit limited, effect (Chen, et al., 2016; Santosaningsih, 2017; Srigley, et al., 2015). Distributing information about health care associated infections rates in the wards may also be effective in giving an overview about hand hygiene practices (IHI, 2006; Trick et al., 2007). Constructive feedback for hand hygiene performance could help to improve adherence to hand hygiene practices (Fuller et al., 2012). Multimodal interventions have been shown to provide a significant improvement in compliance (Allegranzi et al., 2013; Luangasanatip et. Al., 2014; Stewardson, 2016)

This is a cross-sectional study of hand hygiene and therefore it gives only a limited assessment. This study was conducted in a general hospital, and although important results were revealed, the results are still only limited to this governmental hospital context. Similar studies are needed in other different health settings. Further comparisons with these different health settings will be useful in disclosing further valuable information about adherence to hand hygiene protocols among health care workers.

The observational part of this study was small. Some hand hygiene opportunities were missed due to patient and health care worker privacy protection. The study could have been improved by conducting observation in all wards and during all shifts. The study could have been further improved by linking the observational assessment with the self-assessments per respondent; this would have allowed triangulation at individual level. However, this was not possible due to logistic restraints. No 
cross-sectional analysis was done on the freetext suggestions raised by respondents due to the small sample size of this part of the study.

\section{Conclusions}

This study reported that there was a significant correlation between knowledge, attitude, and facilities on the one hand and poor self-reported adherence on the other. It showed that poor adherence was statistically significantly associated with males (63.5\%), untrained staff $(58.5 \%)$ and unavailability of washing basins $(60.4 \%)$. A multimodal improving policy should be adopted. Interventions could involve improving the facilities and positioning hand hygiene supplies and other safety precautions in appropriate places where they can be easily accessed by all health care workers. Furthermore, the protocol of this study can itself be used as an intervention by applying supportive peer observation following the data collection tools employed in this study with immediate feedback assisting the learning process of staff. Reinforcing the importance of the role model in improving hand hygiene could also be highlighted. Staff assume that they are performing hand hygiene but they actually do not adhere; letting them observe each other to learn more about their performance, may reinforce a culture in which "prevention is primary, clean your hands and save lives" (HD, AG, INR).

\section{Acknowledgement}

This study was made possible through the Centre for Strategic Health Studies in Damascus, a capacity building project which was funded by the European Union (The European Commission's Health Sector Modernisation Programme in Syria). Project number: EuropeAid/122215/D/SV/SY.

\section{References}

Allegranzi, B., et al. (2013). Global implementation of WHO's multimodal strategy for improvement of hand hygiene: A quasiexperimental study. The Lancet Infectious Diseases, 13 (10), 843-851.

Centers for Disease Control and Prevention. (2002). Guideline for hand hygiene in health-care settings: Recommendations of the health-care infection control practices advisory committee and the HICPAC/ SHEA/APIC/IDSA hand hygiene task force. Morbidity and Mortality Weekly Report, 51(RR-16).

Chandra, P.N., \& Milind, K. (2001). Lapses in measures recommended for preventing hospital acquired infection. Journal of Hospital Infection, 47, 218-22.

Chen, P., et al. (2016). Role of quality control circle in sustained improvement of hand hygiene compliance: An observational study in a stomatology hospital in Shandong, China. Antimicrobial Resistance \& Infection Control, 5, 54.

Deyneko, A., Cordeiro, F., Berlin, L., Ben-David, D., Perna, S., \& Longtin, Y. (2016). Impact of sink location on hand hygiene compliance after care of patients with Clostridium difficile infection: A crosssectional study. BMC Infectious Diseases, 16, 203.

Eckmanns, T., Bessert, J., Behnke, M., Gastmeier, P. \& Ruden H. (2006). Compliance with antiseptic hand rub use in intensive care units: the Hawthorne effect. Infection Control \& Hospital Epidemiology, 27 (9), 931-934.

Fuller, C. et al. (2012). The Feedback Intervention Trial (FIT) - Improving hand-hygiene compliance in UK healthcare workers: a stepped wedge cluster randomised controlled tiral. PLoS ONE, 7 (10).

IHI. (2006). How-to guide: Improving hand hygiene, a guide for improving practices among health care workers. Cambridge: Institute for Healthcare Improvement.

Lankford, M.G., Zembower, T.R., Trick, W.E., Hacek D.M, Noskin, D.A. \& Peterson, 
L.R. (2003). Influence of role models and hospital design on hand hygiene of health care workers. Emerging Infectious Diseases Journal, 9 (2), 217-223.

Loveday, H.P., Lynam, S., Singleton, J. \& Wilson, J. (2014). Clinical glove use: Healthcare workers' actions and perceptions. Journal of Hospital Infection, 86 (2), 110-116.

Luangasanatip, N., et al. (2015). Comparative efficacy of interventions to promote hand hygiene in hospital: A systematic review. British Medical Journal, 351, h3728.

Mauritio, N., et al. (2014) Do peer effects improve hand hygiene adherence among healthcare workers? Infection Control and Hospital Epidemiology, 35 (10), 1277-1285.

Makay Ö., Içöz G., Yilmaz A. \& Kolcu, F. (2008). Yoğun bakım çalışanlarının el yıkama alışkanlıkları. Ulus Travma Acil Cerrahi Derg., 14 (2), 149-153.

Novoa, A.M. Pi-Sunyer, T. Sala, M., Molins, E., \& Castells, X. (2007). Evaluation of hand hygiene adherence in a tertiary hospital. American Journal of Infection Control, 35, 676-683.

Pittet, D. Mourouga, P., \& Perneger, T.V. (1999). Compliance with handwashing in a teaching hospital. Annals of Internal Medicine, 130,126-130.

Pittet, D., Simon, A., Hugonnet, S., Pessoa Silva, C.L, Sauvan V. \& Perneger T.V. (2004). Hand Hygiene among Physicians: Performance, Beliefs, and Perceptions. Annals of Internal Medicine, 141 (1), 1-8.

Rosenthal, V.D. Guzman, S. \& Safdar, N. (2005). Reduction in nosocomial infection with improved hand hygiene in intensive care units of a tertiary care hospital in Argentina. American Journal of Infection Control, 33, 392-97.

Sacar, S., Turgut, H., Kaleli, I., Cevahir, N., Asan, A., Sacar, M. \& Tekin, K. (2006). Poor hospital infection control practice in hand hygiene, glove utilization, and usage of tourniquets. American Journal of Infection Control, 34 (9), 606-609.

Santosaningsih, D., et al. (2017). Intervening with healthcare workers' hand hygiene compliance, knowledge, and perception in a limited-resource hospital in Indonesia: A randomized controlled trial study. Antimicrobial Resistance and Infection Control, 6 (1), 23.

Srigley, J.A., et al. (2015). Applying psychological frameworks of behaviour change to improve healthcare worker hand hygiene: a systematic review. Journal of Hospital Infection, 9 (3), 202-210.

Stewardson, A.J., et al. (2016). Enhanced performance feedback and patient participation to improve hand hygiene compliance of health-care workers in the setting of established multimodal promotion: a single centre, cluster-randomised controlled trial. The Lancet Infectious Diseases, 16 (12), 1345-1355.

The Joint Commission (2009). Measuring hand hygiene adherence: Overcoming the challenges. Illinois: The Joint Commission.

Trick, W.E,. Vernon, M.O., Welbel, S.F., Demarais, P, Hayden, M.K., Weinstein, R.A. \& Chicago Antimicrobial Resistance Project. (2007). Multicenter intervention program to increase adherence to hand hygiene recommendations and glove use and to reduce the incidence of antimicrobial resistance. Infection Control \& Hospital Epidemiology, 28 (1), 42-49.

Wendt, C., Knautz, D., \& Von Baum, H. (2004) Differences in hand hygiene behavior related to the contamination risk of health care activities in different groups of health care workers. Infection Control \& Hospital Epidemiology, 25 (3), 203-206.

WHO. (2009a). Save live, clean your hands: guide to implementation: A guide to the implementation of the WHO multimodal hand hygiene improvement strategy. Geneva: World Health Organization. 
WHO (2009b). WHO Guidelines on hand hygiene in health care: First global patient safety challenge clean care is safer care. Geneva: World Health Organization.
WHO. (2011). Report on the burden of endemic health care-associated infection worldwide. Clean Care is Safer Care. Geneva: World Health Organization. 